\title{
Asian International Student and Asian American Student: Mistaken Identity and Racial Microaggressions
}

\author{
Hye Jin Tina Yeo ${ }^{\mathrm{a}} \otimes$, Ruby Mendenhall $^{\mathrm{b}} \otimes$, Stacy Anne Harwood ${ }^{\mathrm{c}}$ and \\ Margaret Browne Huntt ${ }^{\mathrm{a} \otimes}$
}

\begin{abstract}
This study examines the experiences of Asian American students who are mistaken as Asian international students; it provides insight into domestic students' perceptions of and potential racial microaggressive experiences of international students. Drawing from racial microaggression survey data of Asian Americans, this study highlights the multiple layers of overt racism, microaggressions, and xenophobia directed against students who are perceived as Asian international students. The Asian American students' narratives reveal that international students are often racialized by skin color, English proficiency, and nationality, which reflect U.S. racist framings of Asian Americans. Thus, we argue that racial experiences of Asian international students should be addressed as a part of U.S. racial ideology, notions of Whiteness, and racial microaggressions on campus.
\end{abstract}

Keywords: race, stereotypes, racial microaggressions, racialization, Asian international students, Asian American students, higher education, racial campus climate

\section{Background}

Over a million international students from different countries attend U.S. institutions of higher education. High enrollment numbers of international students contribute to diversity, knowledge and skill exchanges, financial revenue, and global competence promotion for American college students (Altbach, 2004; Bevis \& Lucas, 2007; Greenblatt, 2005; Hanassab, 2006; NAFSA, 2017). In 2016, international students arrived from over

\footnotetext{
${ }^{\mathrm{a}}$ University of Illinois at Urbana-Champaign.

${ }^{\mathrm{b}}$ Carle Illinois College of Medicine.

${ }^{\mathrm{c}}$ University of Utah.

${ }^{凶}$ Corresponding authors: hyeo8@illinois.edu (Hye Jin Tina Yeo), rubymen@illinois.edu (Ruby Mendenhall), harwood@arch.utah.edu (Stacy Anne Harwood), mbrowne@illinois.edu (Margaret Browne Huntt)
} 
222 countries, composing $5.3 \%$ of all U.S. higher education student populations—with proportions varying by state and district (Institute for International Education [IIE], 2017). Current enrollment growth rates rely on China, India, Saudi Arabia, and Korea (IIE, 2017). International students are often perceived as a monolithic entity in terms of nationality, class, status, and race (Greenblatt, 2005; Kim \& Kim, 2010) within U.S. educational settings. Indeed, international students are invisible from multiculturalism and racial/ethnic diversity discourses (DiAngelo, 2006; Sato \& Hodge, 2009). Given the current uncertain political and social climates that influence immigrants and international students in the United States, this study promotes meaningful discourse around international students' encounters with racial microaggressions (RMAs) as they pursue higher education in U.S. institutions.

Abdullah, Abd Aziz, and Mohd Ibrahim's (2014) review of research on international students revealed that studies tend to rely heavily on students' mobility, academic and general experiences in university settings, and linguistic and cultural challenges. In addition, discrimination and isolation, as factors of international students' experiences, were just briefly mentioned in related literature on the subject (Abdullah et al., 2014). However, there is very limited research that examines international students' experiences with race and racism in U.S. society, the underlying reasons why they experience discrimination, and how they are racialized in systems of U.S. higher education. Likewise, studies are not largely devoted to understanding how international students experience race and racial bias before and after U.S. arrival, with the exception of Ritter (2016). Existing racial taxonomy, and related complexities regarding the reasons for international students' marginalization on U.S. campuses, remains unquestioned and unexamined.

According to Omi and Winant (2015), "race" in the United States depends on meanings, associations, and social practices that permit phenotypic distinctions among human bodies. Race is a social construct and categorization produced through "the act of noticing" others (Martinot, 2003, p. 75), i.e., racialization on a daily basis. Thus, "racialization" occurs when a previously racially unclassified relationship, social practice, or group receives racial labels and meanings imposed externally (Miles, 1988; Omi \& Winant, 1994, 2015). Consequently, international students become "racialized" as they become integrated into U.S. society. In particular, international students of color report a marginalized status and experiences of racial bias and discrimination by the White majority. Such experiences often result in relation to distinct phenotypical characteristics, English accents, nationality, international student status, and religion. Meanwhile, international students from Western and English-speaking countries perceive minimal to no discrimination (Bordoloi, 2014; Bradley, 2000; Constantine, Kindaichi, Okazaki, Gainor, \& Baden, 2005; DiAngelo, 2006; Lee \& Rice, 2007; Poyrazli, Arbona, Bullington, \& Pisecco, 2001; Yeh \& Inose, 2003; Wong, Tsai, Liu, Zhu, \& Wei, 2014). White international students, for instance, were more likely to be perceived as "natives" (White) in the U.S. context. By comparison, international students of color were regarded by peers as "others" (foreigners; Lee \& Rice, 2007; Lewis, 2016).

Employing quantitative analyses, Poyrazli and Lopez's (2007) study found that international students reported higher levels of perceived discrimination and homesickness than U.S. students. Further studies reveal that international students are marginalized based 
on skin color, nationality, gender, and religion via explicit and covert forms of inhospitality and discrimination (Bordoloi, 2014; Houshmand, Spanierman, \& Tafarodi, 2014; Lee \& Rice, 2007; Poyrazli \& Lopez, 2007). Their RMAs and racialization experiences are severely underreported and underresearched (Chong \& Razek, 2014; Kim \& Kim, 2010).

For a discussion about racialization experiences in the U.S. context, it is necessary to define the terms "international students" and "domestic students." This study defines "international students" as students from countries outside the United States, especially those from diverse racial/ethnic, historical, social, cultural, political, linguistic, and religious backgrounds. Background factors are often remarkably different from the host culture. Clarifying the term "international students" to refer to students from different contexts, the study aims to reflect the complexities of relationships among international students and U.S. society. An individual holds different meanings and social identities. The international student recognizes the "self" in a new society with concepts of social constructs not previously imagined. Shifts in perspective signal a necessarily nuanced framework for fuller understandings of the complexities of multidimensional social identities.

This study refers to "domestic students" (mostly White) to indicate students with the U.S. citizenship. This term includes students of color, such as Asian American students, but it is more likely to refer to White students from our data in this paper. This study focuses on how domestic students perceive Asian international students. It addresses biases, prejudices, and RMAs perpetrated against international students through Asian American students' voices. Counter stories of Asian American students, who are often mistaken for Asian international students on campus, are sources for sharing experiences of Asian international students. Examining domestic students' attitudes, interactions, and perceptions of international students provides insight into the racialization experiences of international students attending predominantly White universities. It is critical to understand Asian American students' experiences of RMAs because they have an acute awareness of U.S. racial issues that intersects with international students' experiences. This study aims to disrupt a deficit perspective concerning Asian international students and to reveal unheard stories of discrimination and maltreatment targeting Asian international students. Asian American students' counter-narratives are employed to answer the following research questions:

1. How are Asian international students racialized?

2. What forms of microaggressions do domestic students explicitly express against Asian international students?

3. How are racial microaggressions expressed toward Asian international students similar to or different from racial microaggressions experienced by Asian American students? 


\section{Literature Review}

\section{Racial Experiences of International Students in the United States}

Scholars widely recognize challenges of acculturation and assimilation faced by international students at U.S. universities, such as language barriers, cultural differences, stigma, discrimination, isolation, and pressures for academic performance (Harrison \& Peacock, 2009, 2010; Jon, 2013; Montgomery \& McDowell, 2009; Trice, 2004; Wilton \& Constantine, 2003). Generally, these factors are not regarded by university administrators as part of racial climate issues or a systemic problem within U.S. institutions. Given such climates and lack of attention, international students often mistakenly feel they are implicitly responsible for their experiences of discrimination. One way that international students interpret discrimination as an individual-level problem is by saying it is due to their lowlevel language proficiency or cultural differences, which often cause them to withdraw from academic spheres (Houshmand et al., 2014). Unfortunately, these challenges are generally considered as temporary issues that will decrease once international students become more familiar with American culture and improve their English proficiency. This misguided belief suggests that the responsibilities for adapting to a host culture is a burden that international students must address alone, often without institutional support (Bevis, 2002).

Meanwhile, students from Western and English-speaking countries report minimal to no discrimination (Bordoloi, 2014; Bradley, 2000; Constantine et al., 2005; DiAngelo, 2006; Lee \& Rice, 2007; Poyrazli et al., 2001; Yeh \& Inose, 2003; Wong et al., 2014). International students of color report experiences of racial bias and discrimination due to distinct phenotypical characteristics, English accents, nationality, international student status, and religion. Lee and Rice (2007) theorized verbal and nonverbal insults, ignorance, and negative stereotypes experienced by internationals students as neo-racism. Their neoracism framework focuses on foreign students' status and foreign cultural practices, rather than a continuum of racism embedded in American society.

It is important, however, to consider the continuum of racism because international students are marginalized based on their skin color and race and being viewed as "others" (foreigners; Lee \& Rice, 2007; Lewis, 2016). Poyrazli and Grahame's (2007) focus groups revealed that international students of color experienced subtle discrimination and overt racism on campus during group work assignments. Hostile experiences endured by international students of color (likely Asian or Hispanic students) stood in distinct contrast to the experiences of White German students.

Arguably, patterns of racism and RMAs that American students of color endure are similar to those of international students of color: overt racial slurs and expressed disdain, second-class citizen status, pathologies of cultural values and communication styles, assumptions of criminality, and alienation in their own country(Bonilla-Silva, 2014; Omi \& Winant, 2015; Solórzano, Ceja, \& Yosso, 2000; Sue, 2010a, 2010b; Yosso, Smith, Ceja, \& Solórzano, 2009). Common stereotypes of Asian Americans, such as a "model minority alienated by one's own country" (Sue, Bucceri, Lin, Nadal, \& Torino, 2007), similarly apply to Asian international students (Houshmand et al., 2014). African international students experience stereotypes of criminality, just as African American students in the United 
States (Mwaura, 2008). Consequently, many international students are racialized and socialized by others who use stereotypes of a racial group that is ascribed to them (e.g., African international students are seen as Blacks or Chinese and Korean international students are seen as Asian). These racialized practices occur as international students become integrated into U.S. academic institutions and social settings on and off campus.

A report on the post-2016 U.S. presidential election's impact on academic life and activity at the University of Illinois, Urbana-Champaign, indicated that uncertain political, social, and cultural climates negatively influenced international students' academic performance and their physical and psychological well-being (Chan, 2017). The report indicated anxiety over staying and living in the United States and fear of traveling inside and outside the country. This is true even among those holding permanent residency. International students reported experiencing disadvantages in regard to internships, funding, and employment opportunities because of uncertainty and hostility surrounding matters of work-related immigration.

In this type of campus climate, international students experience difficulties in finding adequate support systems and resources such as legal services. Therefore, they are often fearful and face more difficulty when trying to solve issues (Chan, 2017). A lack of understanding about hostile political and social climates remains an impediment for creating a more sympathetic environment and addressing experiences of overt racism and RMAs that seriously affect international students' psychological and physical well-being (Bradley, 2000; Iwamoto \& Liu, 2010; Meghani \& Harvey, 2016; Mori, 2000; Poyrazli \& Lopez, 2007; Wilton \& Constantine, 2003).

\section{Theoretical Framework and Methodology}

We use EYES theory and counter-storytelling as theoretical and methodological lenses for understanding the experience of Asian international students in a predominantly White institution. An RMA framework is utilized to provide examples of iterative and multiple occurrences whereby international students are discriminated against.

\section{EYES Theory}

Yeo, McKee, and Trent (2018) proposed EYES theory to provide a framework for challenging indifference toward racial experiences of international students and for addressing the process of racialization and racial identity development. EYES uses a visual metaphor for appraisals of self and others through social/cultural/racial stereotypes based on phenotypic traits among international students. International students' eyes may see and perceive issues of race and others (appraisal), continue to change while studying abroad (place), and influence developments of racial identity and views by others from different races (identity). Following race scholars' beliefs, EYES theory starts with the premise that race and racism play key roles in defining and explaining unequal relationships of power and subordination in education (Ladson-Billings \& Tate, 1995; Solórzano, 1997). Racism often manifests by intersecting with other forms of subordination such as gender, class, foreigner status, nationality, language, and culture along with race/ethnicity (Crenshaw, 1991). 
The tenets of EYES theory are (a) international students of color undergo a cataclysmic transition in race concepts as they attempt to integrate into predominantly White universities; and (b) the U.S. racialized campus climates and racial stereotypes rooted in U.S. historical, sociocultural, and political contexts influence the college experiences and identity development of international students of color (Yeo et al., 2018). The intent of the EYES theory is to center race and racism in the racialized U.S. social structure as a filter for the examination of prevailing stories, counter-stories, and constructions of reality that international students encounter on the U.S. campus. The EYES theory challenges deficit perspectives that regard international students as a monolithic entity and global commodity, resulting in their racial experiences being overlooked and invisible. By challenging deficit perspectives, the EYES theory can serve as a useful tool to analyze overt racism and RMAs targeting international students and to provide insights that can improve transitions to predominantly White universities in the United States.

Figure 1 illustrates the framework of this study. The racialized campus climates include, but are not limited to, domestic students, administrators, faculty, hidden curriculums (e.g., injustice of lecture contents and instructions), dominant culture, and policy (e.g., visa acquisition and employment restrictions). Given differing statuses such as citizenship and English proficiency, Asian American students and Asian international students have different degrees of and dissimilar RMAs. The intersection of the two groups, however, implies that both student groups suffer from similar forms of RMAs (e.g., ascription of intelligence, issues regarding language) based on racial/ethnic biases.

\section{RMAs Targeting International Students}

The term "racial microaggression" was first introduced by Chester Pierce in the 1970s to refer to minor acts of discrimination that are experienced frequently by people of color, in particular by African Americans. According to Sue (2010b, p. 3), microaggressions are the everyday verbal, nonverbal, and environmental slights, snubs, or insults, whether intentional or unintentional, that communicate hostile, derogatory, or negative messages to target persons based solely upon their marginalized group membership. Individuals engaged in microaggressions target marginalized groups based on race, gender, sexual orientation, disability, class, and religion, often on a subconscious level.

Further, Kim and Kim (2010) conceptualized microaggressions experienced by international students by adapting Sue's taxonomy (Sue, Capodilupo, et al., 2007). They provided examples of microaggressions that international students encounter: ascription of intelligence; pathologizing cultural values and communication styles; invalidating international perspectives; assumption of homogeneity, exclusion, and social avoidance; invisibility; and environmental and systematic microaggressions. Such microaggressions occur in academic and social places. International students rarely have a support system akin to those given to students of color on U.S. campuses (Chan, 2017; DiAngelo, 2006). They remain marginalized based on skin color, gender, and foreign status.

According to the taxonomy of RMAs (Sue, 2010a, 2010b), four forms of microaggressions are classified: microassaults, microinsults, microinvalidation, and environmental microaggressions. Microassaults, the most overt of the three, are "conscious biased beliefs or attitudes that are held by individuals and intentionally expressed or acted 


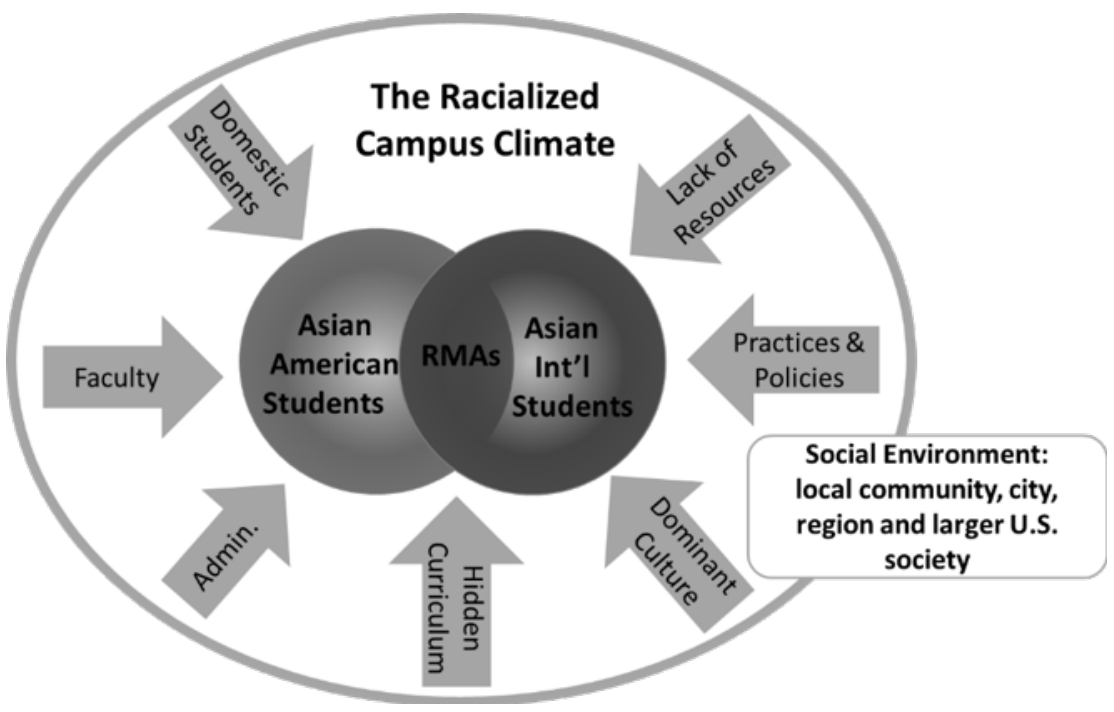

Figure 1. The conceptual framework. Adapted from "EYES Theory: A Proposed Racialization and Developmental Identity Model for Understanding Concepts of Race for International Students of Color Studying in US Higher Education Institutions" by H. J. Yeo, M. McKee, \& W. Trent, in J. Hoffman, P. Blessinger, \& M. Makhanya (Eds.), Perspectives on Diverse Student Identities in Higher Education: International Perspectives on Equity and Inclusion, 2018, Bingley, UK: Emerald. Copyright 2018 by Emerald Publishing.

out overtly or covertly" toward international students (Sue, 2010b, p. 8). The distinct difference of microassaults from the other two forms is that the perpetrator's conscious bias toward an identified and socially devalued group may be directly and publicly expressed. Microinsults, significantly different from microassaults, are "either interpersonal interactions (verbal/nonverbal) or environmental cues that communicate rudeness, insensitivity, slights, and insults that demean” international students' racial, gender, religion, or cultural and national identity (Sue, 2010b, p. 9). Microinsults may present as compliments or positive statements toward the target group, disguising racial bias without guilt. According to Sue (2010a, 2010b), microinvalidations are the most harmful form, presenting a direct attack feature or denial of the target's experiential realities. Microinvalidations occur through "interpersonal and environmental cues that exclude, negate, or nullify the psychological thoughts, feelings, beliefs, and experiences" of international students (Sue, 2010b, p. 10). Environmental microaggressions occur on an institutional level (e.g., policies and recruitment and admission practices) and are evident in the built environment (e.g., images of honor that are predominantly White, classes with one or very few students of color). In other words, these "numerous demeaning and threatening social, educational, political, or economic cues” (Sue, 2010b, p. 25) involve individual, institutional, or societal communication toward marginalized groups. Environmental microaggressions are generally unnoticeable by majority and privileged groups. However, they are often quite visible to minority and underrepresented groups 
such as domestic students of color and international students. Specific examples of environmental microaggressions for international students include policies and practices related to obtaining student visa and work permits; lack of legal, financial, social, and culturally relevant resources and supports; and being viewed as economic commodities during recruitment-related activities. Examining racialized campus climates facilitates understanding and theorizing international students' racial experience and racial identity development in U.S. institutions of higher education.

\section{Counter-Storytelling}

Scholars and researchers employ storytelling in social sciences, humanities, the law, and educational research. Counter-storytelling generally relates to critical race theory frameworks (DeCuir \& Dixson, 2004). Counter-storytelling is defined as a method of "telling the story of those experiences that have not been told" (Solórzano \& Yosso, 2002a, p. 156), and as a tool for "analyzing and challenging the majoritarian stories of racial privilege" (Solórzano \& Yosso, 2002b, p. 32). It involves constructing experiences of marginalized groups to be heard and made visible. Specifically, counter-storytelling "help[s] us understand what life is like for others, and invite[s] the reader into a new and unfamiliar world" (Delgado \& Stefancic, 2001, p. 41). Counter-stories are grounded in reallife experiences, and empirical data draw from contextualized social situations (Solórzano \& Yosso, 2002b). Counter-storytelling is powerful for uncovering the realities of people of color and humanizing experiences to educational research, theory, and practice.

Counter-storytelling can be found in three general forms. These include: personal stories and narratives, composite stories and narratives, and other people's stories and narratives (Solórzano \& Yosso, 2002a, 2002b). Personal stories and narratives describe individual experiences of various forms of racism and oppression (Solórzano \& Yosso, 2002a, 2002b). Such lived experiences can be analyzed within the sociopolitical context in critical race theory and methodology in education (McCoy \& Rodricks, 2015). Composite stories and narratives recount experiences of people of color from various data sources, such as literature or interviews. These sources offer biographical or autobiographical analysis in research (McCoy \& Rodricks, 2015; Solórzano \& Yosso, 2002). Other people's stories and narratives allow individuals to reveal another person's experiences with and responses to racism as told in a third-person voice (Solórzano \& Yosso, 2002). This type of counter-story tends to offer biographical analysis of the experiences of a person of color in relation to U.S. institutions and in a given sociohistorical context (Solórzano \& Yosso, 2002).

Hence, the use of counter-stories provides opportunities to challenge discourses of the majority. In this study, Asian American students' narratives of their experiences with racial targeting recount the experiences of international students' experiences with racism and RMAs. Due to similar phenotypic traits, Asian stereotypes rooted in U.S. racism project onto Asian international students. Such RMAs affect both Asian American and Asian international students' quality of college life and success. In this regard, this study serves as a rare and meaningful way to reveal hidden RMAs experienced by international students studying at U.S. institutions of higher education. 


\section{Research Method}

By engaging in counter-storytelling, this study analyzes Asian American students' counternarratives as a way to examine international students' racial experiences. Asian American students' counter-narratives about racial targeting from Whites due to mistaken international student identity provide context and visibility ("voice") to Asian international students by challenging and uncovering privileged discourses (DeCuir \& Dixson, 2004). This study acknowledges that using Asian American students' counter-narratives to examine international students' racial experiences may be unconventional. Nevertheless, the lived experiences of international students must be documented, drawing from data and existing literature about their racialized encounters. It is critical to attend to Asian American students' experiences of RMAs because, compared to international students, they have a strong, acute awareness of U.S. racial issues. This study offers potential for initiating systemic changes to perceiving international students' racial experience that may lead to positive developments in higher education.

\section{Data}

For purposes of this study, research data relied on a University of Illinois at UrbanaChampaign (UIUC) RMAs survey administered to domestic students of color who attended the university during the 2011-2012 academic year. Over 4,800 students of color completed the survey, a $45 \%$ response rate. The survey respondents included domestic students of color born in the United States. and lawful permanent residents (LPRs). These LPRs, or "green card" holders, are non-U.S. citizens, but they are lawfully authorized to live permanently in the United States and represent $10 \%$ of all students of color who responded to the survey. International students were not included in the sample.

Specifically, this study focused on the Asian students surveyed within the sample group (43\% of respondents reported Asian American identity, both U.S. citizens and LPRs). Table 1 presents background characteristics of just Asian American students who responded to the survey. Regarding citizenship status, $18 \%$ of Asian American students who responded to the survey are green card holders.

The survey included three open-ended qualitative questions: (a) When did you feel uncomfortable, insulted, invalidated, or disrespected by a comment charged with racial overtones? (b) When did others subtly express stereotypical beliefs about race/ethnicity? (c) When did others suggest that you do not belong at the UIUC campus because of your race or ethnicity? Combined, these three questions resulted in approximately 3,000 responses by the Asian American survey participants. The analysis revealed that Asian American students experience pushback, debates, mistaken national identity, backlash against international students on campus, and mental and physical consequences of experiences of RMAs.

\section{Data Analysis}

Asian American students' counter-stories about the racial experiences of international students were coded by employing a directed-content analysis method. The goal of this method is "to validate or extend conceptually a theoretical framework or theory" (Hsieh 
Table 1. Asian American survey participant characteristics as a sample percentage.

\begin{tabular}{ll}
\hline Characteristics & $\begin{array}{l}\% \text { of Asian American Students } \\
(\mathrm{n}=1,509)\end{array}$ \\
\hline Gender & 49.9 \\
Male & 50.0 \\
Female & 00.1 \\
Missing/Other & \\
Student Class & 12.3 \\
Freshman & 18.4 \\
Sophomore & 19.8 \\
Junior & 33.0 \\
Senior & 16.5 \\
Graduate & \\
Science, Technology, Engineering, and mathematics & \\
(STEM) & 47.1 \\
STEM & 52.9 \\
Non-STEM & \\
Citizenship & 81.9 \\
Citizen & 18.1 \\
LPR & \\
\hline
\end{tabular}

Note. $\mathrm{LPR}=$ lawful permanent resident.

\& Shannon, 2005, p. 1281). Directed content analysis helps researchers with coding procedures by indicating pre-identified key concepts or variables. For purposes of this study, the researchers' coding began with four forms of RMAs: microassault, microinsult, microinvalidation, and environmental microaggression (Sue, 2010b). Predetermined themes included alien in own land (Sue, Bucceri, et al., 2007), overt and intentional racial remarks, stereotypes, and assumptions based on race. Additionally, we expected new themes or codes to emerge. Therefore, researchers coded for any reference regarding international students to capture emergent patterns. This includes certain words that were repeated in students' stories such as "international," "mistaken," "lumped," "go back," China/India/Asia/country, "language," "English," and "accent."

Researchers collaborated to identify and develop themes from data and to establish and corroborate final themes. One pattern that emerged was that Asian American students experienced RMAs while being repeatedly mistaken for international students and for being Asian American. To compare themes and forms of RMAs, seven themes were divided into two groups: (a) mistaken identification as international students, and (b) RMAs targeting Asian American students. Table 2 presents groups, themes, definitions, and the relation of themes to RMA categories. 


\begin{tabular}{|c|c|c|c|}
\hline & Theme & RMA Form & Definition \\
\hline \multirow{4}{*}{ 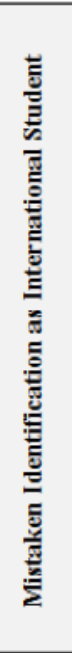 } & $\begin{array}{l}\text { 1. Xenophobia (unwelcome } \\
\text { and hostile campus } \\
\text { climates) }\end{array}$ & $\begin{array}{l}\text { Microassault, } \\
\text { Microinvalidation }\end{array}$ & $\begin{array}{l}\text { Asian American students reportedly heard or } \\
\text { observed xenophobic and bigoted remarks } \\
\text { targeting international students }\end{array}$ \\
\hline & $\begin{array}{l}\text { 2. Mocking English } \\
\text { accents, Asian languages, } \\
\text { and ascription of } \\
\text { intelligence }\end{array}$ & $\begin{array}{l}\text { Microinsult, } \\
\text { Microassault, } \\
\text { Microinvalidation }\end{array}$ & $\begin{array}{l}\text { Asian American students reported hearing or } \\
\text { observing international students' English } \\
\text { accents or Asian languages being mocked. } \\
\text { Sensed judgment as lack of intelligence based } \\
\text { on race and English accent }\end{array}$ \\
\hline & $\begin{array}{l}\text { 3.Overt, direct, intentional } \\
\text { expressions and assaults }\end{array}$ & $\begin{array}{l}\text { Microassault, } \\
\text { Microinsult }\end{array}$ & $\begin{array}{l}\text { Asian American students reported hearing or } \\
\text { observing direct belittling remarks and behaviors } \\
\text { aimed at international students; Asian American } \\
\text { students reported direct insults (insulted or } \\
\text { disrespected) and hatred targeting Asian } \\
\text { American and international students }\end{array}$ \\
\hline & $\begin{array}{l}\text { 4. Being alienated in their } \\
\text { own land }\end{array}$ & $\begin{array}{l}\text { Microinsult, } \\
\text { Microinvalidation }\end{array}$ & $\begin{array}{l}\text { Asian American students reported being } \\
\text { mistaken for foreigners or international students } \\
\text { with disrespectful manners }\end{array}$ \\
\hline \multirow{3}{*}{ 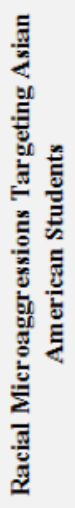 } & $\begin{array}{l}\text { 5. Stereotypes and } \\
\text { assumptions based on race }\end{array}$ & $\begin{array}{l}\text { Microinsult, } \\
\text { Microinvalidation }\end{array}$ & $\begin{array}{l}\text { Asian American students of color reported } \\
\text { encountering stereotypical beliefs about their } \\
\text { race/ethnicity or international students, generally }\end{array}$ \\
\hline & 6. Homogenization & $\begin{array}{l}\text { Microinsult, } \\
\text { Microinvalidation, } \\
\text { Environmental } \\
\text { Microaggression }\end{array}$ & $\begin{array}{l}\text { Asian American students of color reported } \\
\text { pressures to behave like or become White in } \\
\text { White- dominant culture }\end{array}$ \\
\hline & $\begin{array}{l}\text { 7. Monolithic categorization } \\
\text { of Asian American and } \\
\text { Asian International } \\
\text { Students }\end{array}$ & $\begin{array}{l}\text { Microinvalidation, } \\
\text { Environmental } \\
\text { Microaggression }\end{array}$ & $\begin{array}{l}\text { Asian American students of color reported } \\
\text { social pressure to assimilate into White } \\
\text { dominant culture, being lumped together } \\
\text { (conflated), or international students were } \\
\text { lumped together; their interethnic differences } \\
\text { were invalidated }\end{array}$ \\
\hline
\end{tabular}

Figure 2. Racial microaggressions (RMAs) that target international students and Asian American students.

\section{Findings}

Regarding students' lived experiences with RMAs based on their Asian American identity and their mistaken Asian international identity, seven themes emerged. In the mistaken identification group, four themes emerged: (a) xenophobia; (b) mockery of English accents/Asian languages and ascription of intelligence; (c) overt, direct, and intentional expressions; and (d) being alienated in their own land. RMA themes targeting the Asian American students include (e) stereotypes, (f) homogenization, and (g) monolithic categorization of Asian American and Asian international students. Counter-stories of Asian American students respond to the research questions with rich data about how Asian international students are racialized; their experiences with episodic events of White 
normative messages and practices; racial stereotypes; racial slurs; disdainful remarks; and hostile behaviors when classmates, professors, and administrators mistook them for Asian international students. All themes were linked to one or more forms of RMAs (microassault, microinsult, microinvalidation, or environmental microaggression).

\section{Mistaken Identification as International Student}

Asian American students frequently reported being mistaken for international students and hearing or experiencing hostile remarks and racial slurs intended for Asian international students. Asian American students reported talking to Asian international students about their experiences and learning that both were ridiculed and harassed based on their physical features or the way they spoke. The EYES theory informs us that such disdainful comments from White domestic students are derived from historical and sociocultural racism embedded in U.S. social and cultural practices with respect to Asian Americans (Chou \& Feagin, 2015; Yeo et al., 2018)). As a result, the Asian American students surveyed reported feeling uncomfortable and even fearful about being mistaken for international students. Amy, a female Asian American student, remarked that "I feel uncomfortable about being mistaken as an international student because I have heard the unpleasant things people say about them."

\section{Theme 1: Xenophobia}

Xenophobia is a type of racism practiced by people of the same population group toward people with dissimilarities in nationality, ethnicity, language, dress, customs, social and territorial origins, speech patterns, and accents (Kenneth, 2011). The most common xenophobic comments revealed by the students are "Asian invasion," "Asian flush," "too many Asians," "too many international students," "Go back to Asia," or "Go back to [your country, such as India or China]." Asian American students reported encountering groups of students who used such racial slurs mistaking them to be a group of international students. Kim, a female Asian American student, wrote: "Most people on campus have a negative connotation towards Asians and express distaste for international students." Elaine similarly reported hearing someone say, "There are too many Asians on campus. We don't need more." These statements expose the unwelcoming campus climate toward Asian international students. Ultimately, what the students construed from these comments is that Asian students and Asian international students do not belong on campus. The hostility faced by students speaks to the first tenet of EYES theory about the cataclysmic transitions they must endure on predominantly White campuses (Yeo et al., 2018).

Another xenophobic statement frequently reported in the data was that White domestic students believe that international students and foreigners "take jobs away." For example, Daniel reported, "Some people have suggested that I do not belong at the U of I because they unfairly group me with the international students who have 'taken' their jobs or places in graduate schools." To avoid this unpleasant reaction toward international students, some Asian American students such as Anil (male) reported making public their U.S. citizenship to their White peers. 
Being of South Asian descent, people, especially in the college [name], assume I am an international student here to take jobs away from the United States. Every time, in almost all my classes that require group work, I need to let them know that in fact I am an American and I live here in the United States.

Such White student statements reveal a belief that jobs in the United States are supposed to be for Whites or citizens and not individuals from other countries.

In addition to issues around jobs, domestic White students demonstrate discontent with their grade point average and "grading" practices by saying that Asian international students and Asian American students ruin the grading curve because they are "good at math," which is a typical stereotype heard by Asian American students. Eric, a male student, stated, "A student in my [redacted] class was complaining that Asians are ruining the curve because we were apparently good at math." Michelle, a female student, reported, "They say Asians should go back to China and stop taking all the jobs here and ruining the curve." Anna, another female, discussed intelligence and language stereotypes: "Many people associate all Asians as international students who do not belong on this campus because they alter the curve and cannot speak English properly."

Such xenophobic statements from White domestic students reflect prejudicial attitudes toward international Asians. Such attitudes are rooted in U.S. history and structural racism. The EYES theory provides a lens to critically examine this fear expressed by White domestic students about losing status in the job market and in higher education (Yeo et al., 2018). Though they do not necessarily feel they are the targets of xenophobic statements, Asian American students described feeling uncomfortable when witnessing Asian international students being treated unfairly and being targets of RMAs. Asian American students understood that international students were regularly assaulted by xenophobic statements and ridiculed about their English accents and physical features. However, most Asian American students felt that it was unfair to be mistaken for international students.

\section{Theme 2: English Accents, Asian Language Mockery, and Intelligence Ascription}

Asian American students recounted witnessing Asian international students experiencing overt racism and RMAs in the classroom based on their race, foreign names, and English accents. Racial microaggressive behaviors aimed at Asian international students included mocking and imitating English accents and imitating Asian language sounds and intonation-for example, hearing White students say "ching chong."Asian American students with green cards said they were more likely to be treated as international students because of such things as their English accent, English proficiency, or Asian appearance.

A male Asian American student named Jin reported feeling anxious when witnessing international students being treated unfairly or being targets of RMAs. He observed group members mock a female Asian international student's English accent once he left the room. Asian American students also reported that domestic White students judged international students' English proficiency and intelligence based on their appearance and names.In many cases, Asian American students concluded that White students believe 
Asian international students are not capable of learning and teaching at UIUC. This deficit view of Asian students' language proficiency can be predicted using the EYES theory because of the power imbalances between the two racial groups (Yeo et al., 2018).

These racialized beliefs about learning and teaching often play out in the form of microassaults and microinsults when Asian international students serve as teaching assistants (TAs). One Asian American student mentioned that a White male student directly questioned a professor whether the international TAs could speak English. This occurred in front of the entire class just after the professor introduced the TAs at the beginning of the semester. Another Asian American female student, named Jane, described observing an international student TA's struggle in class:

I noticed there was always a struggle for respect and control of the classroom in classes with a high proportion of undergrads. The class's disdain of the TA [from Taiwan] made me really uncomfortable because I felt that it also translated into a judgment of me as a member of the same race-as one who doesn't belong.

Jane directly connected the TA's struggles for control in class to messages that she was receiving about her own sense of belonging on a predominantly White campus.

Asian American students also reported that faculty, academic advisors, counselors, and staff (in and out of the classroom) exhibited condescending attitudes toward Asian international students. This finding is consistent with Hanassab's (2006) research that international students experienced discrimination when interacting with professors and university staff. A female Asian student, Mya, shared her experience: "One of my professors made a comment about international students and the way they speak [and] understand English which I found rather insulting." Due to such hostile climates based on English language proficiency, many Asian American students tried to prove their citizenship by exaggeratedly speaking well-formed English. This similar behavioral pattern was revealed in Kwon, Hernadez, and Moga's (2017) study. They found Asian American students explicitly distinguish themselves from the foreignness of Asian international students by reinforcing English as the standard for inclusiveness.

In addition to reports of mockery toward Asian American and international students' English accents, many Asian American students recalled incidents of mockery and hatred toward Asian languages and culture. The incidents involved conflating, or "lumping together," the nuances between distinct languages, making general remarks about Asian languages and pronunciations, speaking random Chinese-sounding words as "pidjin," and insulting Asian foods.

Asian American students' narratives in this theme embody how domestic students denigrate international students' languages, cultures, or foreign status in subversive and harmful ways through microassaults, microinsults, and microinvalidations.

\section{Theme 3: Overt Expressions of Microassaults Toward Asian Americans and Asian International Students}

Many Asian American students reported overt forms of racial microaggressive behaviors or microassaults in the form of xenophobic remarks around their race and culture, including 
their hair, skin color, food, and fashion sense (see also English accent, above). Anna reported that "Many people believe all Asians are international students on campus. As a result, many people make fun of Asian people for their English, fashion sense, and physical features." Here, EYES theory gives us access to White students' gaze and its related assignment of value and beauty to speech, clothes, and facial features.

Similarly, an Asian male student noted, "Occasionally in interactions with peers, I would hear others mock international students, particularly ones from Asia. They would make comments stating how Asian international students were fresh off the boat, hard to comprehend, and weird." Many other Asian American students told of hearing the phrase "fresh off the boat." Asian American students reported that racial slurs targeting Asian international students tended to be similar to those encountered by Asian American students. This is also true regarding racial prejudices and model minority stereotypes about Asians being "smart" and "good at math." However, students report that along with these stereotypes they have also heard negative beliefs about Asian students in general. An Asian American male student named Ben explained:

The [name] school has a strong Asian minority presence, whether it be Asian Americans or international students. Not so subtly, people notice and comment on how the Asian students are hardworking/study too hard. The general stereotype of they are greedy, self-absorbed, monopolizing on the majors that perform well attitude. In my opinion, this isn't really an incident, but more of a pervading attitude.

Other overt actions and microassaults occurred in social settings. A female Asian American student reported that Asian international students were a major topic of disagreement during deliberations in the recruitment process for her student organization. She felt frustrated with others who questioned how well Asian international students would "fit in" and what they might contribute to the organization. The EYES theory predicts these students will have trouble integrating socially because of explicit and implicit discrimination that marginalizes non-white and perceived non-U.S. students (Yeo et al., 2018).

Asian American students observed that Asian students in general are not welcome when trying to join sororities or fraternities or when attending social events. Reportedly, White students challenged Asian American and Asian international students by asking: "Where do you think you're going?" "I don't think you were invited," or "What [were] all these Asians doing here?" Many Asian American students described their experiences with direct insults and intentional racial slurs. The language included "Fu**ing [or stupid] Asian," "These damn ch**ks," "smelly/dirty Indian," and "terrorist," among others. These overtly hurtful words and behaviors are used by White students to defend White spaces (Harwood, Lee, Riopelle, \& Mendenhall, 2018). As the data suggest, such biased negative perceptions rooted in U.S. racist culture toward Asian American students are also aligned with negative perceptions toward Asian international students. According to the EYES theory, these negative racial filters create cultural and physical borders that continue to segregate students along racial lines (Yeo et al., 2018). 


\section{Theme 4: Being Alienated in Their Own Land}

Consistent with Sue, Bucceri, Lin, Nadal, and Torino's (2007) study, Asian American students in this data were frequently treated as international students or foreigners. This finding revealed disregard for their American citizenship. For instance, Asian Americans of all ethnicities (e.g., Chinese, Korean, Indian, and Vietnamese) encountered expressions such as "Where are you really from?" "Where were you born?" "You speak good English," or "You talk just like us." Students reported that such statements made them feel that they do not belong on campus and that they are not "real" Americans because they are not White or Caucasian. One female student named Sook reflected, "They would emphasize my foreignness_-often in a good way but that makes me feel like I'm not American ... but I am a citizen and also have a strong identity of being Asian American, not just Korean." Sook's statement confirms that RMAs are sometimes delivered by "well-intentioned" White Americans. Such students are often unaware of their false beliefs, misguided intentions, or their racial biases and prejudices about people of color (DeVos \& Banaji, 2005; Sue, 2010b; Sue, Bucceri, et al., 2007).

In addition, Asian American students encountered xenophobic behaviors and comments on campus (see Theme 1) that involved defending the United States as a White country where they did not belong because of their assumed Asian international student status. Students in the data encountered a type of sonic warfare. They described hearing, for example, "This is America, go back to your country," or "This country is not for terrorists." White students racially assaulted Asian students born in the United States, and it follows logically that Asian international students also face xenophobic RMAs. Domestic White students perceive and treat Asian American students and Asian international students through racial lenses and biases that involve alienation associated with race and English accent, which is complicated by mistaken nationality and targeting Asian international students on campus. This white gaze and the patrolling of cultural and physical borders is captured in the second tenet of EYES theory about the U.S. racialized campus climate.

\section{RMAs Targeting Asian American Students}

Building on the mistaken-identity RMA, this section adds examples of other RMAs against Asian American students. We assume that these microaggressions targeted toward Asian American students are also often experienced by Asian international students (mistaken identity in the other direction).

\section{Theme 5: Stereotypes/Assumptions Based on Race}

Asian American students reported that they experienced stereotypical beliefs and statements about their intelligence, such as "Of course you're smart, you're Asian"; "I bet you get really good grades"; or "Oh, I thought Asians were supposed to be good at this stuff." Some Asian American students perceived statements as positive compliments. However, most of them felt both pressured and insulted at being judged through stereotypes. Asian American students recognized abusive behaviors when non- 
Asian domestic students invited them to math- or science-related group projects or tried to copy their exams. A male student named Feng explained,

People usually ask me for help in mathematics or sciences. Then if I get their question wrong, they get mad at me and say, "Aren't you supposed to be good?" I felt like I was a disappointment to this premade stereotype they had of me.

Students reported feeling as though they had to conform to others' stereotypical expectations about them that invalidated their individuality. EYES theory can inform us about the role of filters in influencing how some groups may be viewed as superior or inferior. Our data show that the majority of Asian American students resent the valuing associated with these filters because it flattens their humanity (Yeo et al., 2018).

It is significant to recognize that describing Asian Americans as high achievers and model minorities is a part of a White-named and White-framed perspective (Chou \& Feagin, 2015). Societal atmosphere and culture accept racialized stereotypical comments in everyday discourse as compliments, good humor, or jokes. This is fundamentally problematic because it invalidates recipients' feelings and experiential realities of RMAs. For example, Daniel describes how jokes are not always just jokes:

When my non-Asian friends and I talk about school, I feel insulted when they assume and make general comments that all Asian people are "good at math," "cannot play sports," "seclude themselves in libraries," or any other stereotypes. The comment is usually made in good humor, but that's what insults me-that stereotypes are jokes, and not taken seriously.

As Daniel indicates, stereotypes based on misconceptions of relationships between race and intelligence are harmful to Asian American and Asian international students. Students reported an ascription of unintelligence to international students whose first language is not English while at the same time an ascription of greater intelligence in math and sciences (particularly for Asian international students). This ascribed greater intelligence also comes with an added burden. Asian American students cannot make any mistakes. Such ascriptions of (un)intelligence were identified in Kim and Kim's conceptualization (2010) and Houshmand et al.'s (2014) study. EYES theory can help us to think about how these contradictions set Asian American students up for a cataclysmic transition during their first year of schooling at predominantly white institutions (PWIs; Yeo et al., 2018).

\section{Theme 6: Homogenization}

Most Asian American students in the survey did not find that "Asian American" equates to "American" in the mind of many White students, and Asian American students struggled with how others equated American with being White. Such Whiteness culture and practices were evident at the level of student interaction and socialization (Kwon et al., 2017). Besides being called the model minority, Asian American students described the social pressures from their White peers to behave similarly to them, to become 
Americanized and assimilate into White dominant culture. Bryan, a male student said that "people complain about the large number of 'Asians' (referring in large part to international students) whose English skills and social skills may not be up to par with social norms." These subtextual negative messages about Asian languages, English accents, social skills, and cultures elevate Whiteness as an essential element of America society. Such normative Whiteness is an example of systemic and socially and politically constructed environmental microaggressions. Asian American students report fighting against this perspective that only Whites are real Americans. This limiting belief expressed by White students invalidates racial/ethnical experiences and cultural differences. An Asian male student named Jason recalled that:

I have been called "un-American" as I have a less "American" background ... Roommates made numerous jokes along the lines of implying that I should go back to my "home" country if I don't like the "American" way of thinking ... Roommates often put peer pressure on me saying that these are just "jokes” and they don't mean it and that I shouldn't have to feel offended by it.

These jokes reflect normative Whiteness campus culture and RMAs committed by White peers of Asian American students who do not take responsibility for the detrimental impacts of their actions and remarks. According to Sue (2010b) and Solórzano et al.'s (2000) study, cumulative effects of RMAs perpetrated by "normal, ordinary, and decent people who believe in liberty and the pursuit of justice" can be devastating but often overlooked.

\section{Theme 7: Monolithic Categorization of Asian American and Asian International Students}

Asian American students reported frustration when their White peers engaged in monolithic categorizing. These microinvalidations and environmental microaggressions betray diverse cultures and ethnicities prevalent among Asian American and Asian international students and, according to students, were generally phrased as "All Asians are the same." An Asian American female named Ming stated, "[Due to their] thinking that we are one and the same despite our various cultural differences, some Caucasian male came up and basically stated that all Asians are the same." Another student (Lily) stated, "I've had numerous experiences where White guys would just say stuff to me and my friends in Chinese assuming that every Asian is Chinese." Raj stated the following: "I've been jokingly accused of being a terrorist multiple times because of my skin color."

These monolithic categorizing statements demonstrate how heterogeneity among Asian American and Asian international students is often difficult for White domestic students to perceive and understand. RMAs occurring at the environmental and systemic levels are generally invisible by privileged groups but quite noticeable to minoritized groups such as domestic students of color and international students. Some PWIs enroll international students from over 170 countries who represent a plethora of races and ethnicities. The U.S. categorization systems, and those socialized by them, often fail to acknowledge racial, national, and cultural diversity among international students. For example, Asian international students have only one available category to check on legal 
documents: "Asian." The limits of this large monolithic category are addressed with EYES theory, which seeks to center race and racism in the U.S. context compared to other geographical areas (Yeo et al., 2018).

\section{Discussion}

This study expands the literature on Asian international students' unheard stories of overt racism, microaggressions, and unfair treatment by drawing from Asian American students' historical, social, and racialized counter-narratives and stories to provide insight into the racialized experiences of Asian international students. Asian international students may not fully grasp U.S. historical and sociocultural meanings of race, Asian racial identity, or color consciousness prior to arriving in this country (Fries-Britt, George Mwangi, \& Peralta, 2014; Lewis, 2016; Mitchell, Steele, Marie, \& Timm, 2017). However, extended residency in the United States creates a greater likelihood that Asian international students will perceive and experience U.S. racism (Poyrazli \& Lopez, 2007). In contrast, Asian American students, born and living in U.S. society, more easily recognize racial tones and RMAs that target Asian international students because they are often mistaken for international students or foreigners (Chou \& Feagin, 2015; Sue, Bucceri, et al., 2007). Their stories illustrate harmful racial climates on campus and their consequences for Asian American and Asian international students.

Asian American students' counter-stories demonstrate that Asian international students are racialized by skin color, English proficiency, and nationality. Racialization practices are based on U.S. racist framings of Asian Americans. Identifying race, based on phenotypical characteristics and language-accent mockery, is linked to racial framing and societal discriminating behaviors toward racialized "others" (Chou \& Feagin, 2015; Omi \& Winant, 2015). Moreover, racialized experiences of international students are complex and intertwined with other factors, including nationality, home county status in the global market, economic class, religion, and English proficiency. Findings demonstrate that domestic students, mostly White in our data, view Asian American students and Asian international students through a sometimes (un)conscious racialized lens. Many examples exist where RMAs against Asian international students were conscious and negatively projected onto Asian American students as a form of mistaken identity. The survey responses provided countless examples of stereotypes, such as a "model minority alienated by one's own country" (Sue, Bucceri, et al., 2007). As a result, Asian international students and Asian American students experience similar types of racial microassaults, microinsults, and microinvalidations.

Specifically, both student groups experienced intentional verbal or nonverbal direct attacks: being ridiculed for their English accents and xenophobic bigotry (microassault). They also experienced subtle slights, insensitivity, or rudeness that demeans Asian identity and heritage (microinsults). Asian American students' feelings and racial experiences were often nullified and their racial and cultural diversity negated (microinvalidations and environmental microaggressions). Model minority myths and stereotypes were evident and students described them as insulting (microinsults and environmental microaggressions). In addition, we (authors) perceive specific forms of RMAs occurring within the environmental microaggressions contexts such as pervasive Whiteness culture 
and lack of legal, financial, social, and culturally relevant resources and supports for international students on campus.

For example, our findings demonstrate that White domestic students view themselves as true "Americans" and reify sociocultural pressures that enforce homogenization in higher education. DiAngelo's (2006) research affirms unspoken, unmarked classroom norms and behavioral patterns of Whiteness and White privilege in college classrooms. Further, racial segregation, particularly Asian international students' segregation, is often justified by the pervasive colorblind racism and normative Whiteness on campus. For example, Asian international self-segregation was regarded as the result of international students' lack of action for engagement and lower English language proficiency (Kwon et al., 2017), rather than as a part of the racialized campus climate issues with Whiteness. Moreover, there is a lack of policies, practices, and resources to help international students navigate a complex racism and racial campus climate issues. Indeed, Whiteness culture in U.S. higher education systems harms quality of learning opportunities for Asian international students (DiAngelo, 2006). Whiteness and White privilege bolster advantageous social positions for White students at the expense of Asian American and Asian international students.

Unique racial challenges of international students are disturbingly "invisible" in racial diversity and racial discourses on campus communities (Bradley, 2000)—in part because these students are "seen" as a source of financial revenue. These students are structurally situated at intersecting disadvantages in terms of power relations that include academic and social interactions between second-language speakers and native speakers and social status between foreigners and U.S. citizens. Responsibilities for adjustment are often treated as an individual-level problem to be addressed by international students and with their own resources; the result is a lack of policy and resources for international students (environmental microaggressions). In addition, Asian international students often mistakenly explain discrimination as though they are implicitly responsible. Such a deficit perspective and practices of normative Whiteness by students, faculty, and administrators toward Asian international students in the sample manifested as both overt racism and RMAs.

The findings are consistent with current research, including Houshmand et al.'s (2014) theme, "ridiculed for accent"; Lee and Rice's (2007) theme, "cultural discrimination"; and Kim and Kim's (2010) theme, "pathologizing cultural values/communication styles." This study confirms that Asian international students are not immune to U.S. racial bias and prejudice. As EYES theory (Yeo et al., 2018) proposed, the racialized campus climates and the U.S. racial framing influence Asian international students' college experience and create a gaze that renders students in our sample as one monolithic group. Some experiences appear to be similar to Asian American students' racial experiences; some are dissimilar, because of unequal relationships of power and unique challenges international students face. These experiences create stress for Asian students and shed light on one of the key tenets of EYES theory, a cataclysmic transition to a PWI context that includes unexpected marginalization (Yeo et al., 2018).

Students in the data recognized a need to manage unique challenges that confront them on account of racial discrimination and language (i.e., English proficiency and accent), 
culture, (foreign) name, and international student status at UIUC. Factors of influence are intersectional and intertwined with other factors linked to nationality, political and economic relationships between international students' home country and the United States, home country status in the global market, English proficiency, religion, gender, and race/ethnicity. This study recognizes a need for thorough intersectional microaggression research. Studies need to address the overlooked and complex relationships among U.S. terrains of racial meanings and taxonomies, and the role those relationships play in international students' marginalization on U.S. campuses.

This study highlights the importance of increasing campus discourse and awareness of RMAs that target Asian international students. Institutions should address racial campus climate with educators, administrators, (career) counselors, and students. This study also suggests the need for a dramatic shift in educators' and administrators' views about international students' racialized experiences. Resources are needed for curriculum development, student services, and the creation of institutional training and policies that discourage overt racism and RMAs. As one Asian American student (Amy) stated, the lack of understanding about different cultures and countries "makes me feel like I am unwanted and an eyesore."

To create an inclusive campus learning environments where students do not feel "unwanted," educational leaders, policy makers, faculty, staff, and students must work together to create a supportive and inclusive learning environment. Difficult conversations should occur regularly. The focus should include students' differences (race, class, ability status, etc.) and what these intersecting differences mean for the services required to adequately support a multiracial campus.

\section{Limitations and Future Research Directions}

These study findings contribute to existing literature on RMAs and international students, but they also have limitations. Microaggression themes regarding Asian international students were taken from stories provided by Asian American students who were repeatedly mistaken for Asian international students. Previous research supports the credibility of these findings (Miles, Huberman, \& Saldana, 2014), but to precisely verify international students' racial experiences, future research should include large Asian international student populations in their samples. In addition, we were unable to discern whether RMAs differ by race/ethnicity, nationality, religion, and gender of Asian international students. For example, experiences of RMAs between students from East Asia and students from South Asia may differ. Considering the complexity and diversity of international student population and aspects of RMAs, future research should thoroughly examine intersecting identities on international students' experiences with RMAs.

Further, RMAs and international students' experiences in U.S. higher institutions remain underresearched and undertheorized. International students come from societies with different social concepts of race or with no racial concept. They learn race concepts in diverse ways, and their racial prejudice influences choices of roommates and romantic relationships (Ritter, 2016). Thus, it is important to examine what notions of race, racial hierarchy, and racial stereotypes or bias international students have had based on their home country's contexts. 
The RMAs are spatial practices that shape the experiences of students of color and international students as they move through space (Harwood et al., 2018). Thus, greater empirical research should be performed to investigate racial climates on and off campus, and racial campus climates in larger/smaller cities and rural areas. The different effects of social, cultural, political, and economic contexts on RMAs targeting international students should be examined. In addition, these data were derived from one 4-year institution. Thus, future research should examine whether these findings are transferable to Asian international students on different campuses, including 2-year institutions in the United States. Under the current U.S. administration, campus racial climates have become more challenging for international students (Chan, 2017). Consequently, international students' racialization process and experience of RMAs may be more apparent to them and others now.

\section{Conclusions}

This paper contributes to literature on international students' lived experiences with overt racism and RMAs. The theoretical framework delineates how Asian international students are racialized, and it aims to disrupt false beliefs and racial bias about Asian international students as a mechanism for creating inclusive learning environments. We argue that international students' racial experiences should not be isolated from discourse about the sense of belonging that other students of color at predominantly White universities have.

International students are, often subconsciously, accustomed to attitudes that elevate Whiteness and to practices whereby Whites racialize others, especially in predominantly or traditionally White institutions. What is troubling is that most international students return to their home countries or work abroad, having experienced a lack of campuswide supportive resources and racial experiences. Moreover, they might develop negative biases and prejudices about African Americans or Latinos/as based on their socialization by the larger U.S. society (e.g., media). Many international students become global leaders. We do not want them believing that "they must accept discrimination as the cost of earning an American degree” (Lee, 2007, p. 29). Nor do we want them to have negative feelings about the United States and higher education in the United States. Consequently, it is recommended that researchers, educators, and administrators invest in interventions, including resources for RMA training, workshops on race on U.S. campuses, and addressing students' complex needs.

Since the internationalization and globalization of U.S. higher education will continue, it is important to create inclusive campus climates and increase discourses and practices for understanding diverse global racial and ethnic groups. These investments will foster the development of physical and intellectual safe spaces for international students and decrease the occurrence of microaggressions. Arguably, offering secure and supportive learning environments for students is beneficial on a global scale.

\section{References}

Altbach, P. G. (2004). Higher education crosses borders: Can the United States remain the top destination for foreign students? volume 36 . Change: The. 
Bevis, T. B. (2002). At a glance: International students in the United States. International Educator, 11(3), 12-17.

Bevis, T. B. \& Lucas, C. J. (2007). International students in American colleges and universities: A history. Palgrave Macmillan, New York, NY.

Bonilla-Silva, E. (2014). Racism without racists: Color-blind racism and the persistence of racial inequality in America. Rowman \& Littlefield, Lanham, MD.

Bordoloi, S. (2014). On being brown and foreign: The racialization of an international student within academia. Sociological Imagination, 50(3), 50-66.

Bradley, G. (2000). Responding effectively to the mental health needs of international students. Higher Education, 39, 417-433.

Chan, A. (2017). Report on the post-US Election impact on academic life and activity at the University of Illinois. Urbana-Champaign: University. of Illinois. Available at.

Chong, J. K. \& Razek, N. A. (2014). Feeling welcome with no "buts': Chinese student engagement in residence life. Academy of Educational Leadership Journal, 18(3), 137149.

Chou, R. S. \& Feagin, J. R. (2015). Myth of the model minority: Asian Americans facing racism. Paradigm, Boulder, CO.

Constantine, M. G., Kindaichi, M., Okazaki, S., Gainor, K. A., \& Baden, A. L. (2005). A qualitative investigation of the cultural adjustment experience of Asian international college women. Cultural Diversity \& Ethnic Minority Psychology, 11, 162-175.

Crenshaw, K. (1991). Mapping the margins: Intersectionality, identity politics, and violence against women of color. Stanford Law Review, 43(6), 1241-1299.

DeCuir, J. T. \& Dixson, A. (2004). So when it comes out, they aren't that surprised that it is there: Using critical race theory as a tool of analysis of race and racism in education. Educational Researcher, 33(5), 26-31.

Delgado, R. \& Stefancic, J. (2001). Critical race theory: An introduction. University Press, New York, NY: New York.

DeVos, T. \& Banaji, M. R. (2005). American White? Journal of Personality and Social Psychology, 88, 447-466.

DiAngelo, R. J. (2006). The production of Whiteness in education: Asian international students in a college classroom. Teachers College Record, 108, 1983-2000.

Educational, U. N. (2015). Scientific and Cultural Organization, Institute for Statistics.

Fries-Britt, S., Mwangi, C. A. G., \& Peralta, A. M. (2014). Learning race in a U.S. context: An emergent framework on the perceptions of race among foreign-born students of color. Journal of Diversity in Higher Education, 7(1), 1-13.

Greenblatt, S. (2005). International students and diversity in American higher education. volume 5.

Hanassab, S. (2006). Diversity, international students, and perceived discrimination: Implications for educators and counselors. Journal of Studies in International Education, 10, 157-172.

Harrison, N. \& Peacock, N. (2009). Interactions in the international classroom: The UK perspective. In Jones, E., editor, Internationalisation and the student voice, pages 125142, New York, NY. Routledge. 
Harrison, N. \& Peacock, N. (2010). Cultural distance, mindfulness and passive xenophobia: Using Integrated Threat Theory to explore home higher education students' perspectives on "internationalisation at home.". British Educational Research Journal, 36, 877-902.

Harwood, S. A., Lee, S., Riopelle, C., Mendenhall, R., Huntt, M. B., \& Olorode, T. (2018). Racial microaggressions and spatial belonging: The experiences of students of color at a predominantly white university. Annals of the American Association of Geographers, 108(5), 1245-1259.

Houshmand, S., Spanierman, L. B., \& Tafarodi, R. W. (2014). Excluded and avoided: Racial microaggressions targeting Asian international students in Canada. Cultural Diversity \& Ethnic Minority Psychology, 20(3), 377-388.

Hsieh, H. F. \& Shannon, S. E. (2005). Three approaches to qualitative content analysis. Qualitative Health Research, 15(9), 1277-1288.

Iwamoto, D. K. \& Liu, W. M. (2010). The impact of racial identity, ethnic identity, Asian values and race-related stress on. Asian Americans and Asian international college students' psychological well-being. Journal of Counseling Psychology, 57(1), 79-91.

Jon, J. E. (2013). Realizing internationalization at home in Korean higher education: Promoting domestic students' interaction with international students and intercultural competence. Journal of Studies in International Education, 17, 455-470.

Kenneth, T. (2011). Is xenophobia racism? Anthropology Southern Africa, 34(3\&4), 114121.

Kim, S. \& Kim, R. H. (2010). Microaggressions experienced by international students attending U.S. institutions of higher education. In Sue, D. W., editor, Microaggressions and marginality: Manifestations, dynamics, and impact, pages 171-191, Hoboken, NJ. Wiley.

Kwon, S. A., Hernandez, X., \& Moga, J. L. (2017). Racial segregation and the limits of international undergraduate student diversity. Race Ethnicity and Education.

Ladson-Billings, G. \& Tate, W. I. (1995). Toward a critical race theory of education. Teachers College Record, 97(1), 47-68.

Lee, J. J. \& Rice, C. (2007). Welcome to America? International student perceptions of discrimination. Higher Education, 53, 381-409.

Lewis, A. (2016). Making meaning of race and racialization in the lives of five international graduate students. In Bista, K. \& Foster, C., editors, Exploring the social and academic experiences of international students in higher education institutions, pages 59-78, Hershey, PA. IGI Global.

Martinot, S. (2003). The rule of racialization: Class, identity, governance. Temple University Press, Philadelphia, PA.

McCoy, D. L. \& Rodricks, D. J. (2015). Critical race theory in higher education: 20 years of theoretical and research innovations. ASHE Higher Education Report, 41(3).

Meghani, D. \& Harvey, E. (2016). Asian India international students' trajectories of depression, acculturation, and enculturation. Asian American Journal of Psychology, 7(1), 1-14.

Miles, M. B., Huberman, A. M., \& Saldana, J. (2014). Qualitative data analysis. Sage, Oaks, CA. 
Miles, R. (1988). Racialization. pages 246-247, London, UK. Routledge.

Mitchell, D., Steele, T., Marie, J., \& Timm, K. (2017). Learning race and racism while learning: Experiences of international students pursuing higher education in the Midwestern United States. AERA Open, 3(3), 1-15.

Montgomery, C. \& McDowell, L. (2009). Social networks and the international student experience: An international community of practice? Journal of Studies in International Education, 13(4), 455-466.

Mori, S. (2000). Addressing the mental health concerns of international students. Journal of Counseling and Development, 78(2), 137-144.

Mwaura, J. (2008). Non-traditional age Black African international students' experiences: Phenomenological heuristic inquiry. Adult Education Research.

N.A.F.S.A. (2017). International student economic value tool.

of International Education, I. (2017). Open Doors.

Omi, M. \& Winant, H. (1994). Racial formation in the United States from the 1960s to the 1990s. Routledge, New York, NY.

Omi, M. \& Winant, H. (2015). Racial formation in the United States. Routledge, New York, NY.

Poyrazli, S., Arbona, C., Bullington, R., \& Pisecco, S. (2001). Adjustment issues of Turkish college students in the United States. College Student Journal, 35(1), 52-62.

Poyrazli, S. \& Grahame, K. M. (2007). Barriers to adjustment: Needs of international students within a semi-urban campus. Community. Journal of Instructional Psychology, 34(1), 28-45.

Poyrazli, S. \& Lopez, M. D. (2007). An exploratory study of perceived discrimination and homesickness: A comparison of international students and American students. Journal of Psychology, 141, 263-280.

Ritter, Z. S. (2016). Globalization of racism: Chinese, Japanese, and Korean international students' racial stereotypes and experiences with cross-racial interactions. In Bista, K. \& Foster, C., editors, Exploring the social and academic experiences of international students in higher education institutions, pages 132-155, Hershey, PA. IGI Global.

Sato, T. \& Hodge, S. R. (2009). Asian international doctoral students' experiences at two American universities: Assimilation, accommodation, and resistance. Journal of Diversity in Higher Education, 2(3), 136-148.

Solórzano, D. G. (1997). Images and words that wound: Critical race theory, racial stereotyping, and teacher education. Teacher Education Quarterly, 3, 5-19.

Solórzano, D. G., Ceja, M., \& Yosso, T. J. (2000). Critical race theory, racial microaggressions, and campus racial climate: The experience of African American college students. Journal of Negro Education, 69, 60-73.

Solórzano, D. G. \& Yosso, T. J. (2002a). A critical race counter-story of race, racism, and affirmative action. Equity and Excellence. Education, 35(2), 155-168.

Solórzano, D. G. \& Yosso, T. J. (2002b). Critical race methodology: Counter-storytelling as an analytical framework for education research. Qualitative Inquiry, 8(1), 23-44.

Sue, D. W. (2010a). Microaggressions and marginality: Manifestation, dynamics, and impact. Wiley, Hoboken, NJ. 
Sue, D. W. (2010b). Microaggressions in everyday life: Race, gender, and sexual orientation. Wiley, Hoboken, NJ.

Sue, D. W., Bucceri, J. M., Lin, A. I., Nadal, K. L., \& Torino, G. C. (2007a). Racial microaggressions and the Asian American experience. Cultural Diversity and Ethnic Minority Psychology, 13, 72-81.

Sue, D. W., Capodilupo, C. M., Torino, G. C., Bucceri, J. M., Holder, A. M. B., Nadal, K. L., \& Esquilin, M. (2007b). Racial microaggressions in everyday life: Implications for clinical practice. American Psychologist, 62, 271-286.

Trice, A. G. (2004). Mixing it up: International graduate students' social interactions with American students. Journal of College Student Development, 45(6), 671-687.

Wong, Y. J., Tsai, P. C., Liu, T., Zhu, Q., \& Wei, M. (2014). Male Asian international students' perceived racial discrimination, masculine identity, and subjective masculinity stress: A moderated mediation model. Journal of Counseling, 61(4), 560-569.

Yeh, C. \& Inose, M. (2003). International students' reported English fluency, social support, and social connectedness as predictors of acculturative stress. Counseling Psychology Quarterly, 16(1), 15-29.

Yeo, H. J., McKee, M., \& Trent, W. (2018). EYES theory: A proposed racialization and developmental identity model for understanding concepts of race for international students of color studying in US higher education institutions. In Hoffman, J., Blessinger, P., \& Makhanya, M., editors, Perspectives on diverse student identities in higher education: International perspectives on equity and inclusion, Bingley, UK. Emerald.

Yosso, T. J., Smith, W., Ceja, M., \& Solórzano, D. G. (2009). Critical race theory, racial microaggressions, and campus racial climate for Latina/o undergraduates. Harvard Educational Review, 79(4), 659-690.

\section{Author biography}

Hye Jin Tina Yeo is in Education Policy, Organization, and Leadership at the University of Illinois at Urbana-Champaign. Her major research interests are motivated by the exploration of intersectional identities for international students; specifically how diversity, equity, racial formation, racial identities of international students contribute to identity formation at predominantly White institutions. She also has an interest in racial microaggressions and cultural/racial resiliency.

Ruby Mendenhall is an Associate Professor of Sociology and African American Studies and the Assistant Dean for Diversity and Democratization of Health Innovation at the Carle Illinois College of Medicine. Her research examines how living in racially segregated neighborhoods with high levels of violence affects Black mothers' mental and physical health using surveys, interviews, crime statistics, police records, data from 911 calls, and genomic analysis. She also employs big data to recover Black women's lost history, studies the use of the Earned Income Tax Credit for social mobility, and examines how racial microaggressions affect health and sense of belonging of students of color on predominantly White campuses. 
Stacy Anne Harwood is Professor in the Department of City \& Metropolitan Planning at the University of Utah. Her major research interests include urban planning in multicultural communities; local immigrant integration and planning; racism in everyday integrated spaces; and cross-racial coalition building in working-class White communities.

Margaret Browne Huntt is the Assistant Director for Strategic Research Initiatives and Chief Diversity Officer at the Cancer Center at the University of Illinois at UrbanaChampaign. Her research interests include issues relating to educational inequality and race and ethnicity with a focus on social stratification and mobility, equality of opportunity, and social and organizational change. 